\title{
Does copper tolerance give cadmium tolerance in Mimulus guttatus
}

\author{
G. H. TILSTONE†, M. R. MACNAIR* \& S. E. SMITH \\ Department of Biological Sciences, Hatherly Laboratories, University of Exeter, Prince of Wales Road, \\ Exeter EX4 4PS, U.K.
}

\begin{abstract}
Copper tolerance in Mimulus guttatus Fischer ex DC, is controlled by a single major gene, plus a number of minor genes (or modifiers) which elevate copper tolerance. Homozygous copper tolerant and nontolerant lines derived from Marin County, California, were screened in doseresponse experiments against both copper and cadmium. Significant differences were found between these lines for copper, but not for cadmium, suggesting that cadmium tolerance is not conferred by the major copper tolerance gene. Ten selection lines, derived from three different copper mines, which all carry the major tolerance gene but vary in the degree of tolerance to copper were also screened against copper and cadmium. No significant correlation between copper and cadmium tolerances was found. Screening of modifier lines, in which modifiers for differing degrees of copper tolerance were inserted into a nontolerant background, showed that genotypes possessing fewer copper modifiers yield higher cadmium tolerance than those genotypes which have a greater number of modifiers. These results suggest that copper and cadmium tolerance are governed by independent genes in this species.
\end{abstract}

Keywords: cadmium tolerance, copper tolerance, cotolerance, linkage disequilibrium, Mimulus guttatus, pleiotropy.

\section{Introduction}

Metal tolerance in plants has excited much study as a classic example of microevolution and adaptation (Antonovics et al., 1971; Macnair, 1987). One of the aspects of this phenomenon which still remains unclear is the specificity of tolerance. It was initially suggested that tolerance to one metal does not confer tolerance to others (Gregory \& Bradshaw, 1965; Turner, 1969; Ernst, 1974). However, Bradshaw et al. (1965) showed that tolerance is not necessarily specific, and that nickel tolerance can occur in a zinc-tolerant population of Agrostis capillaris L., despite the absence of high soil nickel contamination from the parent environment. Turner \& Gregory (1967) were the first to use the term cotolerance, and further examples have been given by a number of authors (Cox \& Hutchinson, 1979; Hall, 1980; McGrath et al., 1980; Wong, 1982; Hertstein \& Jager, 1986; Von Frenckell-Insam \& Hutchinson, 1993a,b; Patra et al., 1994). Verkleij \& Prast (1989) were the first to suggest copper-

\footnotetext{
*Correspondence. E-mail: m.r.macnair@exeter.ac.uk

Present address: Instituto de investigacions mariñas, Eduardo Cabello, 6-36208, Vigo, Spain.
}

cadmium cotolerance in higher plants using five populations of Silene vulgaris (Moench) Garcke. Symeonidis et al. (1985) showed that copper-tolerant populations of $A$. capillaris also had elevated levels of tolerance to other heavy metals, including cadmium. Allen \& Sheppard (1971) observed that the highly copper-tolerant population of Mimulus guttatus Fischer ex DC from the Copperopolis mine also had a high mean tolerance to zinc, lead and nickel, even though these metals were not present substantially in the soil from this mine, and suggested that metal tolerance in this species was general to many heavy metals. M. R. Macnair and Q. J. Cumbes (unpublished observation) found that the Copperopolis population also showed a high tolerance to cadmium, and this observation prompted the present study.

Generally, in these papers, cotolerance has been inferred from correlations between population mean values (Cox, 1986) and the within-population correlation has been assumed to be the same. Clones from the same site vary in tolerance responses to copper, nickel, cobalt and zinc (Hogan \& Rauser, 1979) and variations in tolerance to different metals occur in A. capillaris (Karatagalis, 1982). In addition, 
there appears to be some confusion in the literature over the term cotolerance. Wong (1982) has claimed cotolerance in Festuca rubra L. to copper, lead and zinc, but in the same paper refers to this tolerance as multitolerance. Verkleij \& Prast (1989) refer to genes for one metal conveying tolerance to other metals as cross-tolerance. Some authors have described cotolerance as tolerance to metals which are not present in the test site soil (Bradshaw et al., 1965; Symeonidis et al., 1985).

Cotolerance is suggested because of a correlation between tolerance to two metals. There are two processes that can give rise to such a correlation. The first is pleiotropy, where the same gene(s) and presumably physiological processes produce tolerance to both metals. The second is linkage disequilibrium, where the sample of individuals tested happens to have a greater proportion of $A B$ and $a b$ than expected on the basis of the frequency of $A$ and $B$ individually (where $A$ and $B$ are alleles giving tolerance to two different metals). Testing for tolerance at the population level will, almost inevitably, produce linkage disequilibrium, even where the genes are not linked. The work of Cox \& Hutchinson $(1979,1980)$ illustrates this problem. They first described cotolerance (= pleiotropy) to copper and nickel in Deschampsia cespitosa (L.) Beauv (Cox \& Hutchinson, 1979), but then presented evidence for multiple metal tolerance (= linkage disequilibrium) to copper, nickel, aluminium, zinc, lead and cadmium (Cox \& Hutchinson, 1980). Von Frenckell-Insam \& Hutchinson (1993a) later suggested that coppernickel tolerance in this species is also not a result of cotolerance. In reality, the best way of distinguishing between linkage disequilibrium and pleiotropy is by a genetic analysis, through which the independence of genes for different metals can be studied (Macnair, 1993). Few genetic analyses of this kind have been undertaken. An exception is the work of Humphreys \& Nicholls (1984), who found no cotolerance between copper, lead and zinc in $A$. capillaris, using $\mathrm{F}_{1}, \mathrm{~F}_{2}$ and backcross families from interpopulation hybrids. However, Schat \& ten Bookum (1992a) using $\mathrm{F}_{2}$ crosses suggested that copper tolerance also gives tolerance to zinc in $S$. vulgaris.

The genetics of metal tolerance has recently been reviewed by Macnair (1993). There is increasing evidence that, for some metals at least, tolerance is controlled primarily by one or a few major loci, with additional modifier genes that increase tolerance. This model has been shown to be true for copper tolerance in M. guttatus (Macnair, 1983; Macnair et al., 1993; S. E. Smith \& M. R. Macnair, unpublished observations and S.vulgaris (Schat \& ten Bookum, 1992b; Schat et al., 1993). Much less is known about cadmium tolerance in higher plants, although Collard \& Matagne (1990) found two major genes for cadmium tolerance in Chlamydomonas reinhardtii, which give cadmium tolerance both singly and additively. Baker et al. (1986, 1990) have shown that cadmium tolerance may develop as a consequence of phenotypic plasticity. Individuals that are not genetically tolerant to cadmium can have tolerance induced by exposure to low levels of the metal.

Where tolerance is controlled by major genes with hypostatic modifiers, cotolerance could occur with either the major gene(s) or the modifiers, or both. This paper investigates the cause of the cadmium tolerance found in copper-tolerant populations of M. guttatus from Calaveras Co., California, testing specifically whether either the major copper-tolerance locus, or the modifiers, give cadmium tolerance pleiotropically.

\section{Materials and methods}

\section{Major genes}

Isogenic lines were established from crosses made between plants collected by Sheppard (Allen \& Sheppard, 1971) and nontolerant plants collected from Stinson beach, Marin Co., CA, USA, by Macnair. These lines consist of homozygous tolerant and nontolerant plants which differ only at the major gene for copper tolerance (Macnair, 1983). Screening these lines against copper and cadmium would show whether or not the major gene gives pleiotropic cadmium tolerance.

\section{Modifiers of copper tolerance}

Selection lines Five independent pairs of selection lines derived from three copper mines with differing copper contamination were used to test whether modifiers of copper tolerance conferred cadmium tolerance. Each pair of lines was selected both for increased ( $\mathrm{H}$ line) and decreased ( $\mathrm{L}$ line) tolerance. Three pairs of lines were derived from Copperopolis (see Allen \& Sheppard, 1971; Macnair et al., 1993). The first, which had been selected for six generations $\left(\mathrm{H}_{6}\right.$ and $\left.\mathrm{L}_{6}\right)$, had originally been established from pooled seed from the whole of the mine. The other two were established from seed from the northern and southern areas of the mine, respectively, and had been selected for four generations $\left(\mathrm{NH}_{4}, \mathrm{NL}_{4}, \mathrm{SH}_{4}, \mathrm{SL}_{4}\right)$. The final two pairs of lines were selected from the Quail and Penn mines, and had been selected for three generations $\left(\mathrm{QH}_{3}, \mathrm{QL}_{3}\right.$, 
$\mathrm{PH}_{3}, \mathrm{PL}_{3}$ ). Penn lies $32.5 \mathrm{~km}$ to the north-west of Copperopolis, and Quail is $14.0 \mathrm{~km}$ due west (Allen \& Sheppard, 1971). In all lines the downward lines were selected at $1.0 \mu \mathrm{g} \mathrm{cm}^{-3} \mathrm{Cu}$, which ensures that individuals are tolerant, albeit of low tolerance. Thus the difference between the lines is caused by the accumulation of modifiers, but all lines are homozygous for the major copper-tolerance gene. Details of the selection protocol are given elsewhere (Macnair et al., 1993; Harper et al., 1997).

Modifier lines The hypostatic tolerance modifiers have been separated from the tolerance gene by crossing highly tolerant individuals to the isogenic nontolerant line, and screening nontolerant segregants from the $F_{2}$ of this cross for their ability to increase the tolerance of the isogenic tolerant line. Details of the crossing programme will be given elsewhere (S. E. Smith \& M. R. Macnair, unpublished observations); in this paper six individuals are used which either increase tolerance by a small amount $\left(\mathrm{ML}_{1} ; \mathrm{ML}_{2}\right)$, an intermediate amount $\left(\mathrm{MI}_{1} ; \mathrm{MI}_{2}\right)$ or a large amount $\left(\mathrm{MH}_{1} ; \mathrm{MH}_{2}\right)$. Note that all six individuals do not possess the major tolerance gene, and are not tolerant to copper.

\section{Clones and random-sampled populations}

A nonmine population (CL40), collected from an uncontaminated pasture in Calaveras Co., was also screened at a range of both copper and cadmium concentrations and the results were compared to dose-response curves for a random selection of 10 individuals from the original Copperopolis population and the isogenic copper-tolerant lines.

\section{Methodology}

All selection lines were grown and raised as in Macnair et al. (1993). Ten cuttings from each line were harvested at between 5 and $15 \mathrm{~cm}$ height and were then tested at $0.0,0.5,1.0,1.5$ and $2.0 \mu \mathrm{g} \mathrm{cm}^{-3} \mathrm{Cd}$, and $0.0,0.5,1.0,2.0$ and 3.0 $\mu \mathrm{g} \mathrm{cm}^{-3} \mathrm{Cu}$, with calcium nitrate addition at $0.5 \mathrm{~g} \mathrm{~L}^{-1}$. Cuttings were grown in $200 \mathrm{~mL}$ polystyrene cups in continual light, constant temperature/humidity growth cabinets. Solutions were changed on the fourth and sixth days and the longest root of each cutting scored on the eighth day (Wilkins, 1978). Copper was added as $\mathrm{CuSO}_{4} \cdot 5 \mathrm{H}_{2} \mathrm{O}$. and cadmium as $\mathrm{Cd}\left(\mathrm{NO}_{3}\right)_{2} \cdot 4 \mathrm{H}_{2} \mathrm{O}$.

\section{Soil metal content}

Soil samples were collected from each of the populations in Calaveras Co. Two replicates of five samples were taken from both north and south Copperopolis and Quail. Two replicates of two samples were taken from Penn and CL40 soil, and two replicates of 10 samples were taken from Stinson Beach. The soils were air-dried at $50^{\circ} \mathrm{C}$ and sieved through a $2 \mathrm{~mm}$ stainless steel mesh. About $15.0 \mathrm{~g}$ of soil was ground to a fine powder in an agate pestle and mortar. $0.25 \mathrm{~g}$ of powdered soil was digested in $10 \mathrm{~mL} \mathrm{HNO}_{3}$ at $115^{\circ} \mathrm{C}$ overnight and then at $175^{\circ} \mathrm{C}$ to remove the acid. $10 \mathrm{~mL} 1 \mathrm{M} \mathrm{HCl}$ with 10 per cent sodium (as a releasing agent) was added to the remaining residue, which was subsequently filtered through Whatman no. 6 filter papers. Extractable copper and cadmium contents were obtained following Allen (1989). $50 \mathrm{~mL}$ of $1 \mathrm{M}$ ammonium acetate, with 10 per cent sodium releasing agent were added to $2.0 \mathrm{~g}$ of soil in $100 \mathrm{~mL}$ volumetric flasks, and then placed on a rotary shaker for $1 \mathrm{~h} .25 \mathrm{~mL}$ of the resulting solution was filtered through Whatman no. 6 filter papers. In both cases, copper and cadmium content $\left(\mu \mathrm{g} \mathrm{g}^{-1}\right)$ were determined using a Pye Unicam SP9 AAS. Standards were made from $1000 \mu \mathrm{g} \mathrm{cm}^{-3} \mathrm{BDH}$ spectrosol solution and were matched with 10 per cent $\mathrm{Na}$ and either $1 \mathrm{~m} \mathrm{HCl}$ (for total metal) or $1 \mathrm{~m}$ ammonium acetate (for extractable metal).

\section{Results}

\section{Isogenic lines}

The dose-response curves for the isogenic tolerant and nontolerant lines (Fig. 1a) to copper are significantly different $\left(F_{4,90}=4.41, P=0.003\right)$, as expected. When grown in cadmium, however, no significant difference $\left(F_{4,90}=0.74, \quad P=0.566\right)$ was found between the lines (Fig. 1b).

\section{Selection lines}

Figure 2 gives dose-response curves for both copper (Fig. 2a) and cadmium (Fig. 2b) for the six selection lines derived from Copperopolis. The six lines differ significantly in tolerance to both copper $\left(F_{20,270}=1.76, P=0.025\right)$ and cadmium $\left(F_{20,270}=1.66\right.$, $P=0.040)$, with, as expected, the high lines being more tolerant to copper than their corresponding low lines. They are also, however, more tolerant to cadmium (Fig. 2b). This could be interpreted as evidence for cotolerance between copper and 
cadmium tolerance for the modifiers responsible for the difference between upward and downward lines.

The results of screening the four further selection lines from the Penn and Quail mines are given in Fig. 3. The four lines differ significantly in copper tolerance $\left(F_{12,180}=5.50, P<0.001\right)$ with the high lines being more tolerant than the low lines (Fig. 3a). No significant differences were found between the lines for cadmium tolerance $\left(F_{12,180}=1.43, P=0.156\right.$ ) (Fig. $3 b$ ). In the Penn and Quail populations, therefore, it appears that cadmium tolerance is governed by different genes from the copper-tolerance modifiers.

Figure 4 represents the mean tolerance index values at $1.0 \mu \mathrm{g} \mathrm{cm}^{-3}$ copper and cadmium for the 10 selection lines. A low correlation was recorded
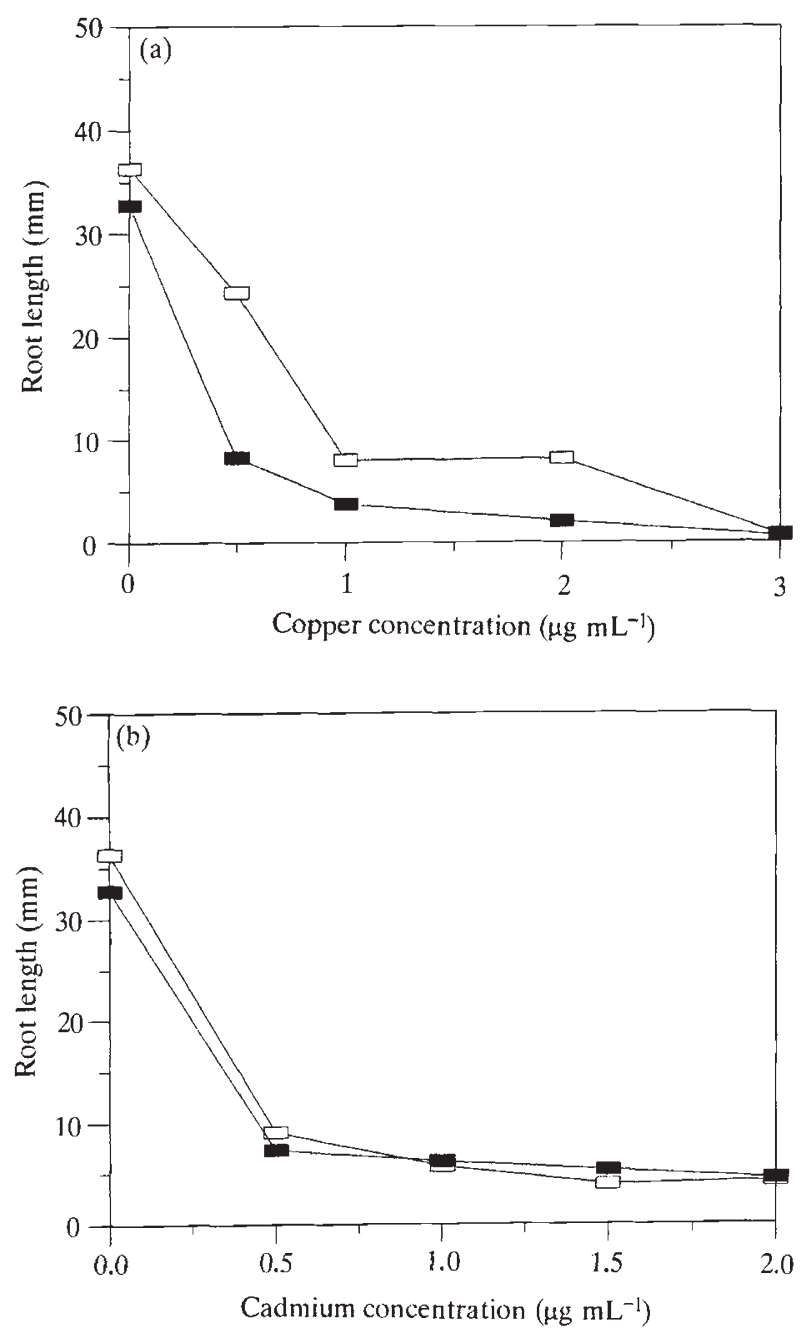

Fig. 1 Copper (a) and cadmium (b) dose-response curves for tolerant $(\square)$ and nontolerant $(\square)$ isogenic lines of Mimulus guttatus. between the copper and cadmium data for both tolerance index (rank correlation $=0.013$ ) and root length (rank correlation $=0.085$; data not shown).

\section{Modifier lines}

Two-way ANOVA, using genotype nested within modifier type, showed no significant differences for copper tolerance $\left(F_{8,12}=0.19, \quad P=0.987\right), \quad$ as expected, because all of these lines are nontolerant to copper (Fig. 5a). Figure 5b gives the data for cadmium tolerance. The six lines differed significantly in cadmium tolerance $\left(F_{8,12}=1.81, P=0.171\right)$ with the two intermediate lines $\left(\mathrm{MI}_{1}\right.$ and $\left.\mathrm{MI}_{2}\right)$ and one high line $\left(\mathrm{MH}_{1}\right)$ showing higher tolerance than the two low lines and the other high line.
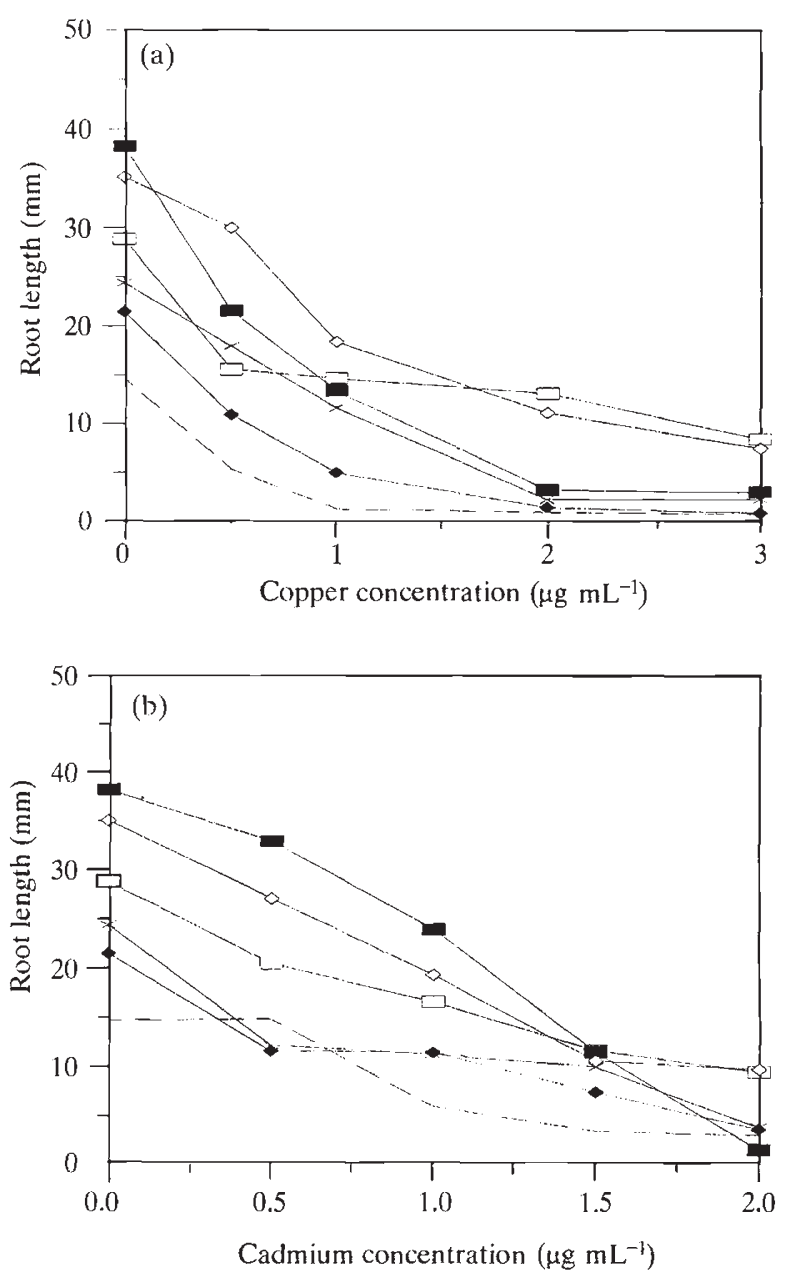

Fig. 2 Copper (a) and cadmium (b) dose response for selection lines from Mimulus guttatus Copperopolis mine, Calaveras Co. $\mathrm{H}_{6}(\square), \mathrm{L}_{6}(\square), \mathrm{NH}_{4}(\diamond), \mathrm{NL}_{4}(\diamond), \mathrm{SH}_{4}(\mathrm{X})$, $\mathrm{SL}_{4}(---)$.

(C) The Genetical Society of Great Britain, Heredity, 79, 445-452. 


\section{Clones and random-sampled populations}

Figure 6 gives dose responses for individuals from CL40, the isogenic tolerant line and a random sample of individuals from the Copperopolis population to copper and cadmium. When tested with copper (Fig. 6a), the populations show the expected order of tolerance: CL40 (nontolerant), isogenic tolerant, Copperopolis. To cadmium, however (Fig. 6b), CL40 shows equal tolerance to Copperopolis, and both are more tolerant than the isogenic tolerant plant.

\section{Soil analysis}

Table 1 gives the metal contents of the Calaveras Co. sites. CL40 and Stinson Beach have very low
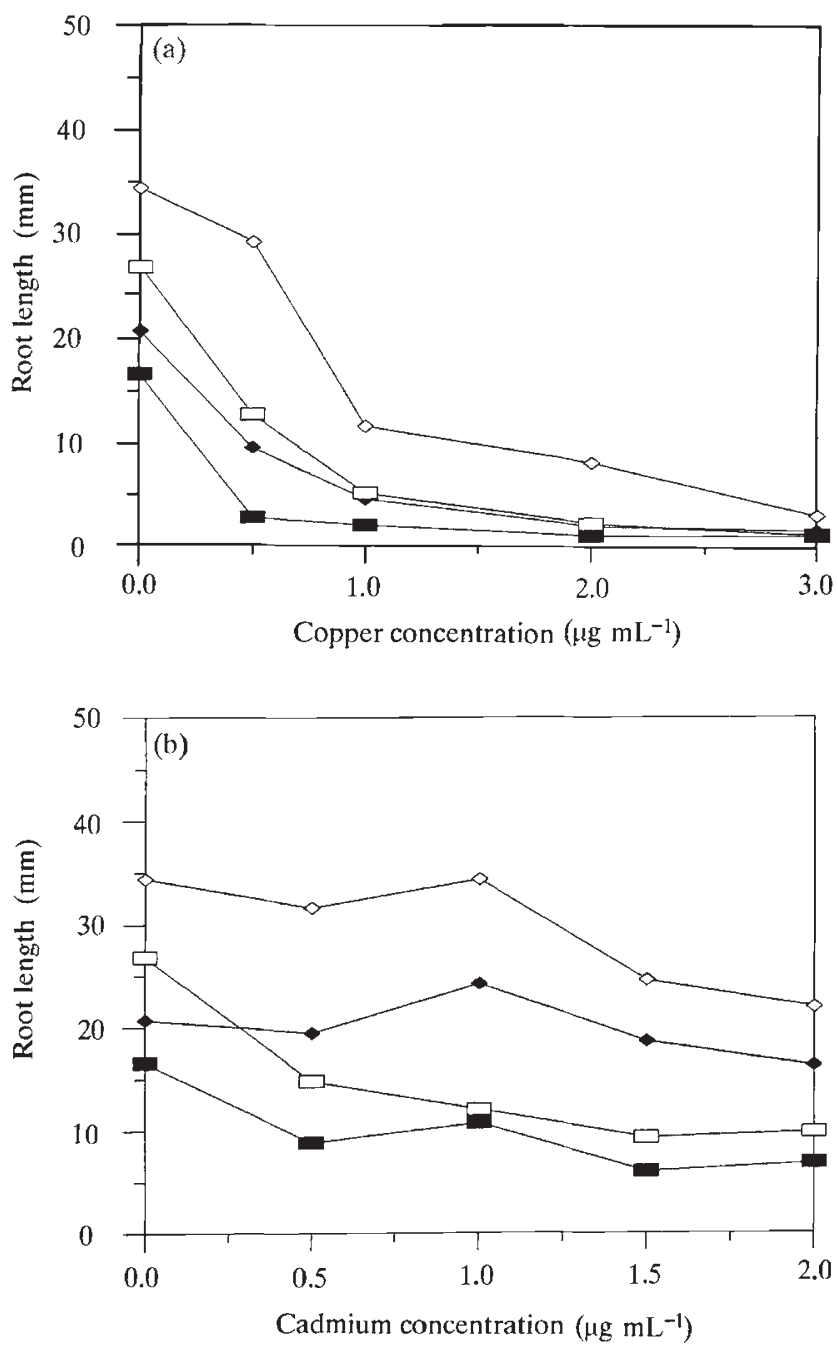

Fig. 3 Copper (a) and cadmium (b) dose response for selection lines of Mimulus guttatus from Penn and Quail mines, Calaveras Co. $\mathrm{QH}_{3}(\diamond), \mathrm{QL}_{3}(\diamond), \mathrm{PH}_{3}(\square), \mathrm{PL}_{3}(\mathbf{\square})$.

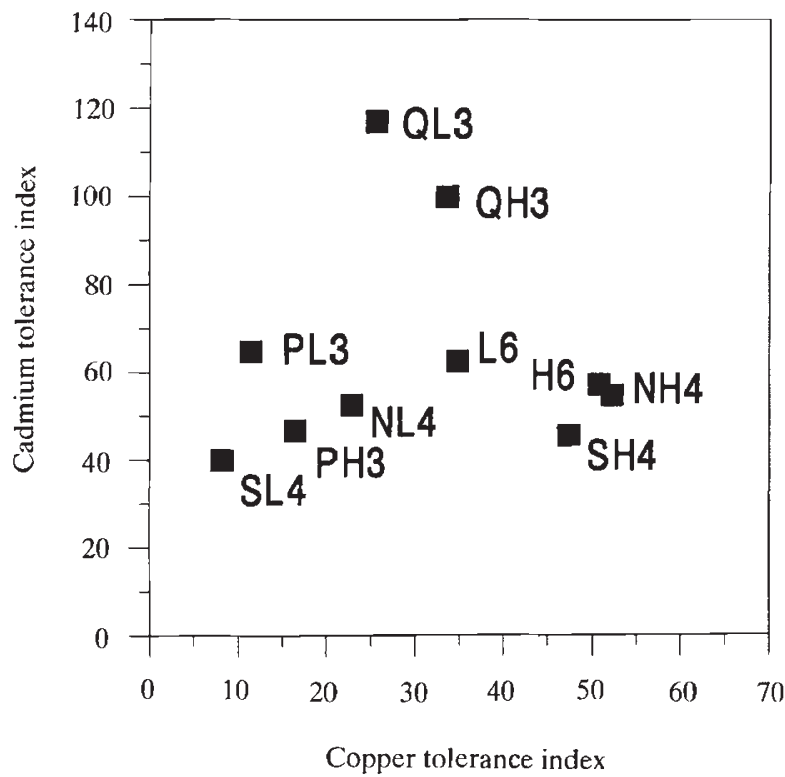

Fig. 4 Plot of copper- and cadmium-tolerance indices at $1.0 \mu \mathrm{g} \mathrm{cm}^{-3} \mathrm{Cu}$ and $\mathrm{Cd}$ for Copperopolis, Penn and Quail high and low selection lines of Mimulus guttatus.

levels of both copper and cadmium, whereas Copperopolis has more copper than the Penn or Quail mines, with the northern end of the mine being more contaminated than the southern end. Quail and Penn have more cadmium than Copperopolis.

\section{Discussion}

The data presented here give no support to the hypothesis that the genes responsible for copper tolerance in $M$. guttatus also confer cadmium tolerance pleiotropically. Copper tolerance in this species is governed by a single major gene (Macnair, 1983) with one or more hypostatic modifiers (S. E. Smith \& M. R. Macnair, unpublished observations). Either class of gene could have conferred cadmium tolerance. Using isogenic lines that differ only in the copper-tolerance locus we have shown that the tolerant and nontolerant lines do not differ in cadmium tolerance, thus indicating that the major gene does not convey tolerance to this metal. Two strategies were adopted to test whether the modifier genes give pleiotropic cadmium tolerance. First, selection lines which had been selected for increased or decreased copper tolerance were screened for their tolerance to cadmium: a correlated response in this latter character would have suggested that the modifiers producing increased copper tolerance could also confer copper tolerance. Although some lines 
did show an increase in cadmium tolerance, there was no consistent pattern, and overall there was no correlation between the copper tolerance of the lines and their cadmium tolerance. The second approach was to screen lines which differed in their genotype at the copper-tolerance modifier loci. Again no correlation attributable to pleiotropy was obtained.

However, the high tolerance to cadmium of the Copperopolis population, and indeed all the mine populations studied in Calaveras Co., remains unexplained. The only mine with a significant cadmium content is Quail (Table 1), and this population does indeed have the highest cadmium tolerance. However, the other mines, whose soil contains less cadmium than the maximum permitted in agricultural soils ( $=2.0 \mu \mathrm{g} \mathrm{g}^{-1}, \mathrm{SAOMC}, 1992$ ), also have much higher tolerance to this metal than the
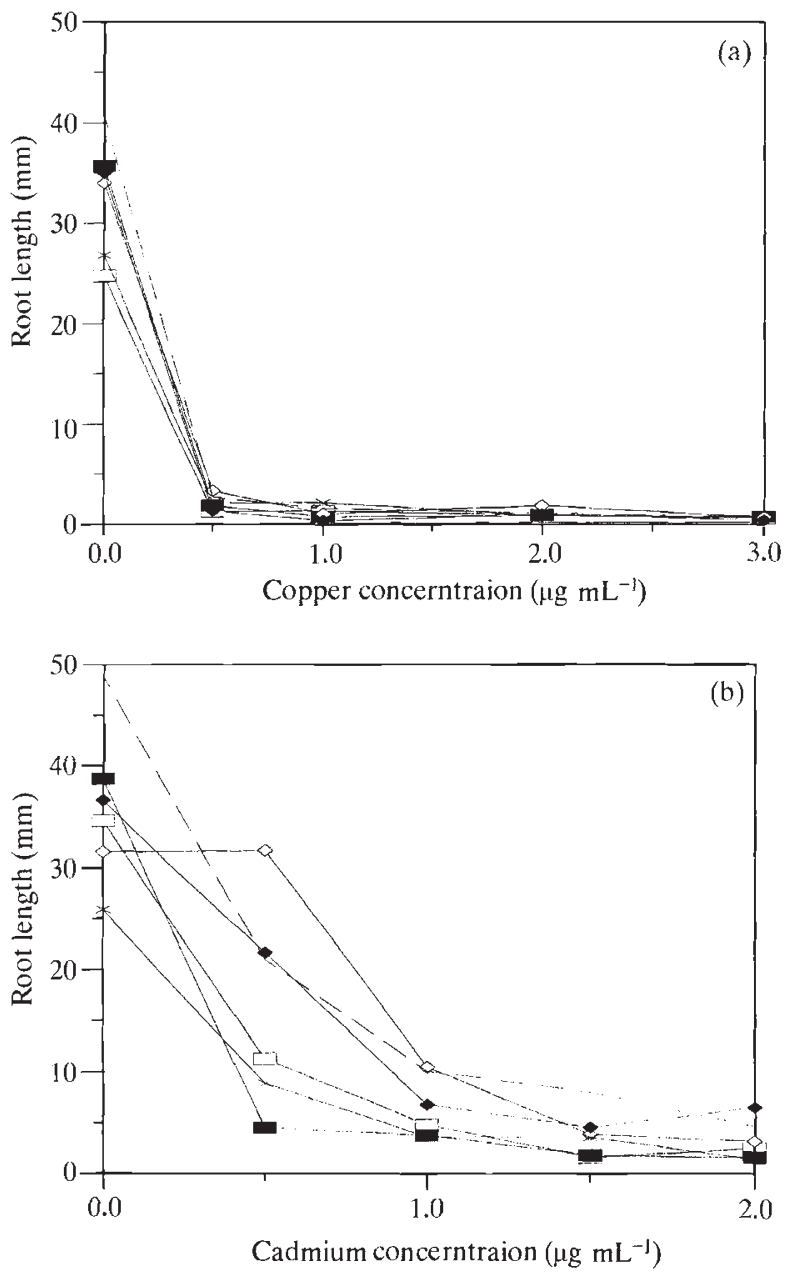

Fig. 5 Copper (a) and cadmium dose-response curves for modifier lines of Mimulus guttatus. $\mathrm{ML}_{1}(\square), \mathrm{ML}_{2}(\mathbf{\square}), \mathrm{MI}_{1}$ $(\diamond), \mathrm{MI}_{2}(\diamond), \mathrm{MH}_{1}(\mathrm{X}), \mathrm{MH}_{2}(---)$. isogenic lines. It is this sort of observation, that mine populations have tolerance to metals that are not elevated at that site, that has led a number of authors to postulate cotolerance (Bradshaw et al., 1965; Symeonidis et al., 1985). However, a nonmine population from the same area, CL40, which was not copper tolerant, was also far more cadmium tolerant than the isogenic lines (Fig. 6), having a level of tolerance equal to Copperopolis. This observation suggests that the high cadmium tolerance of these populations from Calaveras Co. is a property of all the local populations, i.e. that the gene(s) for cadmium tolerance are fixed in M. guttatus from this region of California. The cause of this difference between the Stinson Beach population (from the
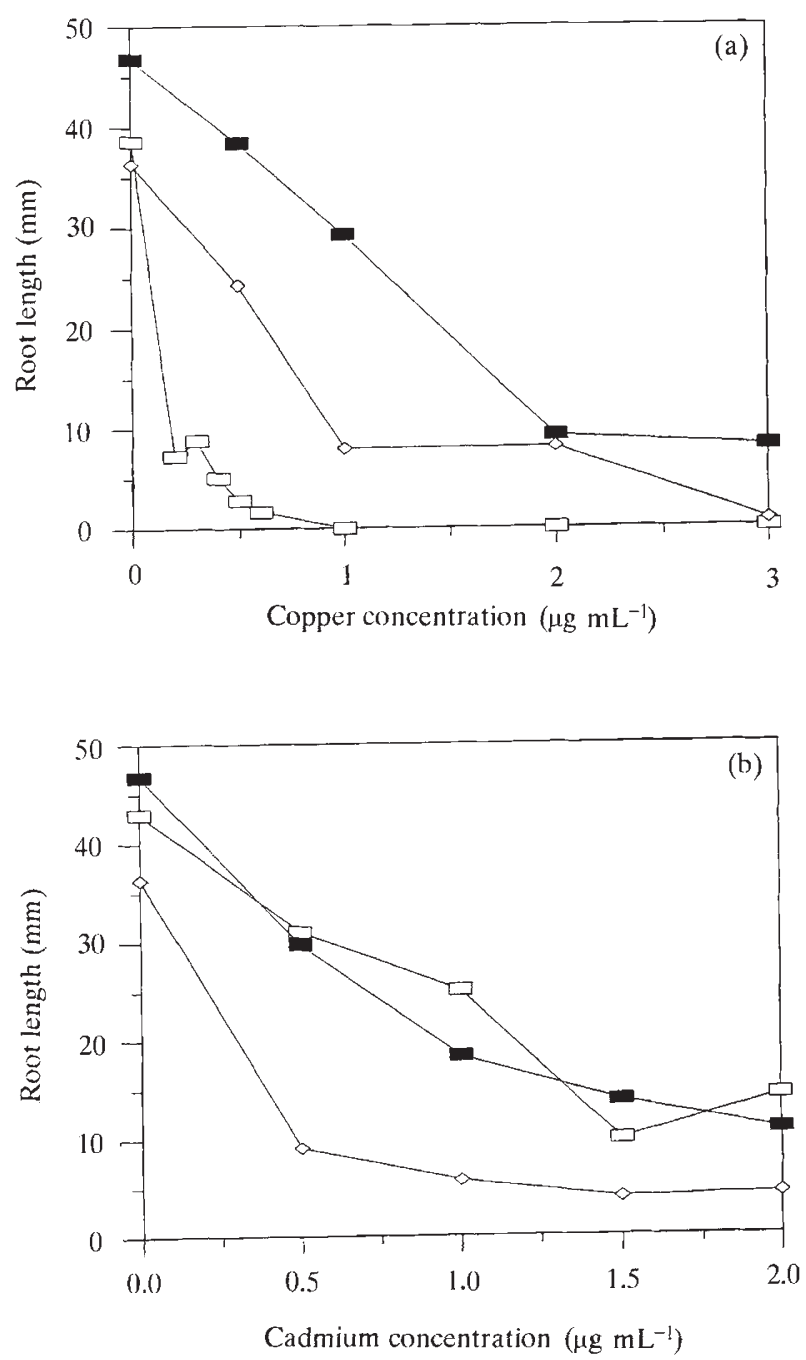

Fig. 6 Copper (a) and cadmium (b) dose-response curves for CL40 (a nonmine population) ( $\square$ ), a random sample of the Copperopolis mine population (a) and the isogenic tolerant line of Mimulus guttatus $(\diamond)$.

(c) The Genetical Society of Great Britain, Heredity, 79, 445-452. 
Table 1 Total and ammonium acetate extractable copper and cadmium contents of soils from the populations studied in this paper

\begin{tabular}{lrccc}
\hline & $\begin{array}{c}\text { Total Cu } \\
\mu \mathrm{g} \mathrm{g}^{-1}\end{array}$ & $\begin{array}{c}\text { Total Cd } \\
\mu \mathrm{g} \mathrm{g}^{-1}\end{array}$ & $\begin{array}{c}\text { Extractable Cu } \\
\mu \mathrm{g} \mathrm{g}^{-1}\end{array}$ & $\begin{array}{c}\text { Extractable Cd } \\
\mu \mathrm{g} \mathrm{g}^{-1}\end{array}$ \\
\hline Quail & 808.00 & 9.57 & 126.12 & 5.70 \\
Penn & 519.30 & 7.01 & 38.24 & 1.98 \\
N. Copperopolis & 6549.80 & 2.35 & 592.84 & 0.28 \\
S. Copperopolis & 2183.70 & 2.46 & 60.48 & 0.27 \\
Mean Copperopolis & 4366.75 & 2.40 & 326.66 & 0.27 \\
Stinson Beach & 1.18 & 0.02 & $0.00^{*}$ & $0.00^{*}$ \\
CL40 & 22.65 & 0.76 & 0.68 & $0.00^{*}$ \\
\hline
\end{tabular}

*Below the detection limits of the SP9 Unicam AAS

Coastal Mountains) and these populations (from the Sierra Nevada) is unknown.

\section{Acknowledgements}

We would like to thank Quinton Cumbes, Phil Goodson and James Kingdom for their technical assistance. G.H.T. was supported by NERC studentship GT/4/93/19/L; part of this research was also funded by NERC grant GR91707A to M.R.M. We thank an anonymous referee for criticism on an earlier draft which greatly improved this paper.

\section{References}

Al.ten, S. E. 1989. Chemical Analysis of Ecological Materials, 2nd edn. Blackwell Scientific Publications, Oxford.

AI.l.EN, W. R. AND SHEPPARD, P. M. 1971. Copper tolerance in some Californian populations of the monkey flower Mimulus guttatus. Proc. R. Soc. B, 177, 177-196.

ANTONOVICS, J., BRADSHAW, A. D. AND TURNER, R. G. 1971. Heavy metal tolerance in plants. Adv. Ecol. Res., 7, $1-85$.

BAKER, A. J. M., GRANT, C. J., MARTIN, M. H., SHAW, S. C. AND WHITEBROOK, J. 1986. Induction and loss of cadmium tolerance in Holcus lanatus L. and other grasses. New Phytol., 102, 575-587.

BAKER, A. J. M., EWART, K., HENDRY, G. A. F., THORPE, P. C. AND WAIKER, P. L. 1990. The evolutionary basis of cadmium tolerance in higher plants. In: Barcelo, J. (ed.) Proceedings of the Fourth International Conference on Environmental Contamination, Barcelona, pp. 23-29. CEP Consultants Ltd, Edinburgh.

BRADSHAW, A. D., MCNEILIY, T. AND GREGORY, R. P. G. 1965. Industrialization, evolution and development of heavy metal tolerance in plants. In: Goodman, G. T., Edwards, R. W. \& Lambert J. M. (eds) Ecology and the Industrial Society, The British Ecological Society Symposium No.5, pp. 327-344. Blackwell Scientific Publications, Oxford.
COILARD, J. M. AND MATAGNE, R. F. 1990. Isolation and genetic analysis of Chlamydomonas reinhardtii strains resistant to cadmium. Appl. Env. Microbiol., 56, 2051-2055.

Cox, R. M. 1986. Contamination and effects of cadmium in native plants. Experientia, 50, 101-109.

COX, R. M. AND Hutchinson, T. c. 1979. Metal cotolerance in the grass Deschampsia cespitosa. Nature, 279, 231-233.

COX, R. M. AND HUTCHINSON, T. C. 1980. Multiple metal tolerances in the grass Deschampsia cespitosa (L.) Beauv. from Sudbury smelting area. New Phytol., 84, 631-647.

ERNST, W. H. O. 1974. Schwermetallvegetation der Erde. Gustav Fischer Verlag, Stuttgart.

GREGORY, R. P. G. AND BRADSHAw, A. D. 1965. Heavy metal tolerance in populations of Agrostis tenuis Sibth. and other grasses. New Phytol., 64, 131-143.

HALI, A. 1980. Heavy metal co-tolerance in a copper tolerant population of the marine fouling alga, Ectocarpus siliculosus (Dillw.) Lyngbye. New Phytol., 85, 73-78.

HARPER, F. A., SMITH, S. E. AND MACNAIR, M. R. 1997. Where is the cost in copper tolerance in Mimulus guttatus? Testing the trade-off hypothesis. Funct. Ecol. (in press).

HERTSTEIN, U. AND JAGER, H. J. 1986. Tolerances of different populations of three grass species to cadmium and other metals. Env. Exp. Bot., 26, 309-319.

HOGAN, G. D. AND RAUSER, w. E. 1979. Tolerance and toxicity of copper, nickel, and zinc in clones of Agrostis gigantea. New Phytol., 83, 665-670.

HUMPHREYS, M. O. AND NICHOLL.S, M. K. 1984. Relationships between tolerance to heavy metals in Agrostis capillaris (=Agrostis tenuis Sibth.). New Phytol., 98, 177-190.

KARATAGLIS, S. S. 1982. Combined tolerance to copper, zinc and lead by populations of Agrostis tenuis. Oikos, 38, 234-241.

McGRATH, S. P., BAKER, A. J. M., MORGAN, A. N., SALMON, W. J. AND WIILIAAMS, M. 1980. The effect of interactions between cadmium and aluminium on the growth of two metal tolerant races of Holcus lanatus L. Envir. Poll. (ser. A), 23, 267-277. 
MACNAIR, M. R. 1983. The genetic control of copper tolerance in the yellow monkey flower, Mimulus guttatus. Heredity, 50, 283-293.

MACNAIR, M. R. 1987. Heavy metal tolerance in plants: a model evolutionary system. Trends Ecol. Evol., 2, 354-359.

MACNAIR, M. R. 1993. Tansley Review no. 49. The Genetics of metal tolerance in vascular plants. New Phytol, 124, 541-559.

MACNAIR, M. R., SMITH, S. E. AND CUMBES, Q. J. 1993. Heritability and distribution of variation in degree of copper tolerance in Mimulus guttatus at Copperopolis, California. Heredity, 71, 445-456.

PATRA, J., LENKA, M. AND PANDA, B. B. 1994. Tolerance and co-tolerance of the grass Chloris barbata Sw. to mercury, cadmium and zinc. New Phytol., 128, 165-171.

SAOMC. 1992. Standards for Organic Food and Farming. Rev. 5 The Soil Association Organic Marketing Company Ltd, Bristol.

SCHAT, H. AND TEN BOOKUM, W. M. 1992a. Metal-specificity of metal tolerance syndromes in higher plants. In: Baker A. J. M., Proctor, J., Reeves R. D. (eds) The Vegetation of Ultramafic (Serpentine) Soils, pp. 337-352. Intercept, Andover.

SCHAT, H. AND TEN BOOKUM, w. M. 1992b. Genetic control of copper tolerance in Silene vulgaris. Heredity, 68, 219-229.

SCHAT, H., KUIPER, E., TEN BOOKUM, W. M. AND VOOIJS, R. 1993. A general model for the genetic control of copper tolerance in Silene vulgaris: evidence from crosses between plants from different tolerant populations. Heredity, 70, 142-147.
SYMEONIDIS, L., MCNEILLY, T. AND BRADSHAW, A. D. 1985. Differential tolerance of three cultivars of Agrostis capillaris L. to cadmium, copper, lead, nickel and zinc. New Phytol, 101, 309-315.

TURNER, R. G. 1969. Heavy metal tolerance in plants. In: Rorison I. H. (ed.) Ecological Aspects of Mineral Nutrition of Plants. British Ecological Society Symposium, Vol. IX, pp. 399-410. Blackwell Scientific Publications, Oxford.

TURNER, R. G. AND GREGory, R. P. G. 1967. The use of radioisotopes to investigate heavy metal tolerance in plants. In: Isotopes in Plant Nutrition and Physiology, pp. 439-509. IAEA/FAO, Vienna.

VERKLElJ, J. A. C. AND PRASt, J. E. 1989. Cadmium tolerance and co-tolerance in Silene vulgaris (Moench.) Garcke (=S. cucubalus (L.) Wib.). New Phytol., 111, 637-645.

VON FRENCKELL-INSAM, B. A. K. AND HUTCHINSON, T. C. 1993a. Occurrence of heavy metal tolerance and cotolerance in Deschampsia cespitosa (L.) Beauv. from European and Canadian populations. New Phytol., 125, 555-564.

VON FRENCKELL-INSAM, B. A. K. AND HUTCHINSON, T. C. 1993b. Nickel and zinc tolerance and co-tolerance in populations of Deschampsia cespitosa (L.) Beauv. subject to artificial selection. New Phytol., 125, 547-553.

WILKINS, D. A. 1978. The measurement of tolerance to edaphic factors by means of root growth. New Phytol., 80, 623-633.

WONG, M. H. 1982. Metal cotolerance to copper, lead and zinc in Festuca rubra. Env. Res., 29, 42-47. 